\title{
Blood styrene and urinary metabolites in styrene polymerisation
}

\author{
M. S. WOLFF, W. V. LORIMER, R. LILIS, AND I. J. SELIKOFF \\ From the Environmental Sciences Laboratory, Mount Sinai School of Medicine of the City University \\ of New York, USA
}

ABSTRACT The results of the analysis of blood and urine samples for styrene and its metabolites in 491 workers in a styrene polymerisation plant in the United States are reported. The levels of exposure to styrene were estimated to be less than $10 \mathrm{ppm}$, but nevertheless styrene and metabolites were detectable in more than $50 \%$ of workers in polymerisation jobs, within $4 \mathrm{~h}$ of exposure. Workers involved in the manufacture and purification of styrene from ethyl benzene also had detectable blood styrene and urinary metabolites in $83 \%$ of recently exposed subjects. The relationship between styrene in blood and in subcutaneous fat and urinary metabolites as pharmacokinetic variables is discussed.

Various indices of human exposure to organic solvents have been investigated in recent years in recognition of the fact that air sample analysis, even at best, may be an inadequate measure of individual environmental exposure. This results from the frequent difficulty of obtaining an accurate or representative personal sample and of the many changes in levels of exposure during actual working conditions over short periods of time. At the same time the non-uniformity of human responses, even to similar exposure levels, has been noted. Individual variation in absorption, distribution, storage, metabolism and excretion can be marked.

Efforts to assess individual exposure quantitatively have dealt with measurement of unaltered materials (such as styrene, benzene, dichloromethane, trichloroethylene and various anaesthetics) in expired air and blood, and of urinary metabolites including trichloroacetic acid (for trichloroethylene), phenols (for benzene), hippuric acid (for toluene), and mandelic or phenylglyoxylic acid (for styrene) (Riley et al., 1966; Stewart et al., 1968; Stewart et al., 1970; Hunter and Blair, 1972; Sherwood, 1972; Corbett, 1973; Szadkowski et al., 1973). For many of these compounds, under either controlled experimental or measured occupational exposures, the biological exposure indices correlate well with the concentration of the compound in air during exposure. Several aspects of these questions have been reviewed by Astrand (1975).

Received for publication 26 May 1977

Accepted for publication 18 January 1978
The need to monitor low exposures to styrene appears to be important, as carcinogenic risk is currently being assessed, partly because of the effects seen in workers with another vinyl monomer, vinyl chloride (Creech and Makk, 1975), the mutagenic behaviour of styrene oxide (Milvy and Garro, 1976), and animal studies with various vinyl monomers: trichloroethylene (Chemical and Engineering News, 1976), vinyl chloride (Maltoni and Lefemine, 1975), vinylidene chloride (Maltoni, 1977; Lee, 1977) and acrylonitrile (Murray et al., 1976).

In particular, styrene (phenylethylene, vinyl benzene) inhalation response has been well characterised by breath and blood levels during controlled experimental exposures at 50-200 ppm, which approximates to the TLV* (Stewart et al., 1968; Astrand et al., 1974). Thus breath and blood concentrations measured within $6 \mathrm{~h}$ of exposure can be correlated with ambient exposure levels greater than $50 \mathrm{ppm}$, and urinary metabolites, measurable for at least $16 \mathrm{~h}$ after exposure can also be correlated with previous exposure. Recently, measurement of subcutaneous fat concentrations of styrene in 25 occupationally exposed subjects from the group to be described in this paper showed that styrene could be detected in fat for as long as three days after exposure (Wolff et al., 1977).

The use of urinary metabolites as an exposure index has special merit in industrial hygiene evaluation, because it does not require an invasive

*TLV $=$ Threshold Limit Value of the American Conference of Governmental Industrial Hygienists 
technique and because the analytical method is fairly simple and has been extensively studied. Nevertheless, the usefulness of urinary metabolite measurements for styrene is limited by the fact that observed levels, which reach a maximum at 8-12 h after exposure, become insignificant within 16-24 h (Bardodej and Bardodejova, 1970). For any estimation of body burdens more than 16-24 h after exposure, an alternative exposure index is necessary.

Further, although urine analysis is valuable as a screening method for exposures in excess of $50 \mathrm{ppm}$ (time-weighted average), insensitivity of present methods limits its use at lower levels of exposure (Schaller et al., 1976). Even at low exposures, however, urinary metabolite determinations may be potentially useful for identifying sporadic exposures such as those incurred from accidental spills or other unusual exposures which would not be recognised by air sampling (time-weighted average). The analytic method of choice is now gas chromatography, which allows detection of at least $10 \mathrm{mg} / \mathrm{l}$ of mandelic acid, and eliminates a confounding background level of $90-250 \mathrm{mg} / \mathrm{l}$ with the formerly used colorimetric method (Engstrom and Rantanen, 1974).

The absorption-elimination measurements of styrene exposure, established under controlled laboratory conditions, have been applied to a limited number of industrial situations, with excellent results. Thus, the data of Gotell et al. (1972) for 17 occupationally exposed subjects were entirely analogous to previously reported exposure criteria derived from laboratory experiments. Initial breath concentrations and decay curves for styrene correlated well with exposure data derived from personal air sampling. Urinary metabolites were similarly related to exposure, although some evidence of a levelling effect at higher exposure ( $>150 \mathrm{ppm}$ ) was presented. In another study among 21 Japanese workers, urinary metabolites were also representative of exposure levels (Ohtsuji and Ikeda, 1970), and two Swedish studies of 36 and 47 workers showed a good curvilinear relationship between end-of-shift urinary metabolites and time-weighted average styrene exposure (Harkonen et al., 1974; Engstrom et al., 1976). The correlation at levels of exposure less than $100 \mathrm{ppm}$ appeared to be linear, and the authors in both studies suggested that for an end-of-shift urine (which should represent a metabolite concentration near its peak) a urinary metabolite concentration of less than $2300 \mathrm{mg} / \mathrm{g}$ creatinine or $3000 \mathrm{mg} / \mathrm{l}$ would indicate an exposure below the current TLV of $100 \mathrm{ppm}$.

Urinary mandelic acid concentrations were recently reported for a group of 58 German styrene polymerisation workers exposed to less than $8 \mathrm{ppm}$ styrene (Thiess et al., 1976). Mandelic acid in urine samples obtained immediately after work was below $105 \mathrm{mg} / \mathrm{l}$ in all cases and below $50 \mathrm{mg} / 1$ in all but two, with 38 above $10 \mathrm{mg} / \mathrm{l}$.

Considering the variety of methods involved, the reported values of urinary mandelic acid correlate remarkably well with exposure levels (Fig. 1). Blood styrene concentrations previously reported are summarised in Fig. 2, where an estimated blood styrene of less than $0.1 \mathrm{ppm}$ can be extrapolated for exposure levels. of $10 \mathrm{ppm}$ styrene.

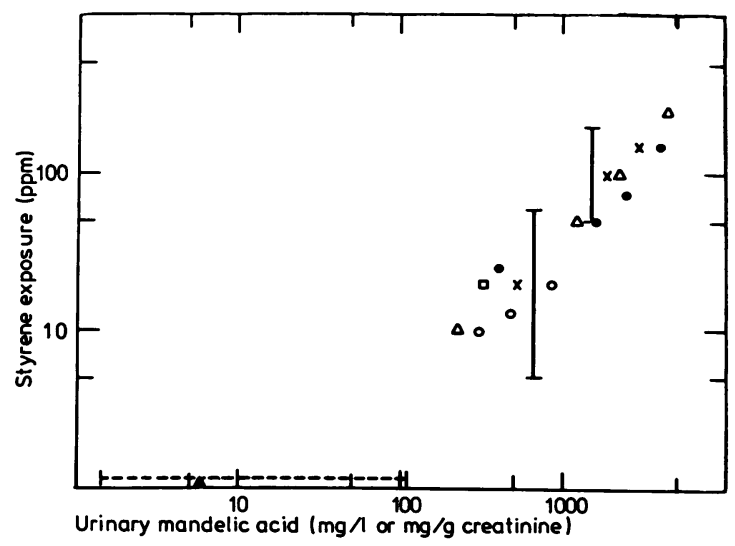

Fig. 1 Correlation of styrene exposures with reported concentrations of urinary mandelic acid. $\bigcirc$ Ohtsuji and Ikeda, 1970; - Harkonen et al., 1974; × Gotell et al., 1972; I Ikeda et al., 1972; $\triangle$ Engstrom et al., 1976; A Slob, 1973; $\square$ Bardodej and Bardodejova, 1970 ;- . . . . - Thiess et al., 1970.

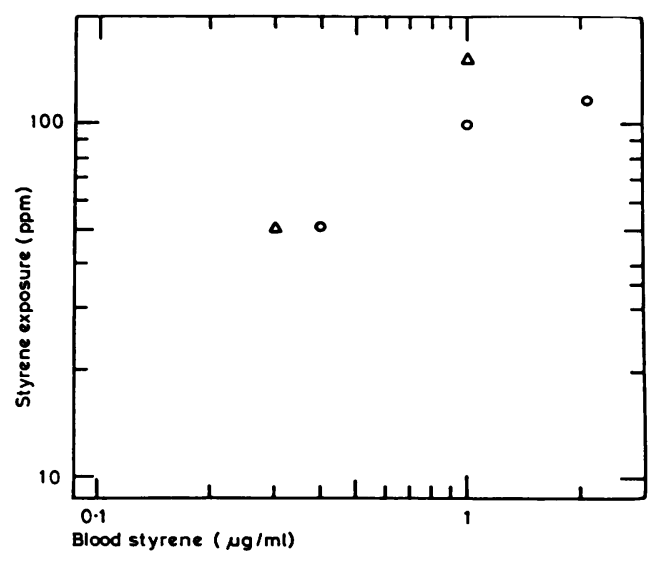

Fig. 2 Relation of styrene exposure to styrene concentration in venous blood. $\triangle$ Astrand et al., 1974; O Stewart et al., 1968. 


\section{Materials and methods}

During a clinical field survey of 491 workers in a styrene polymerisation plant in December 1975, we had the opportunity to compare the concentration of styrene in blood with urinary metabolites and, in 25 cases, in subcutaneous fat. These workers were exposed to a variety of styrene concentrations and had widely different work experience.

The styrene plant in which the workers investigated in this study were employed produced styrenebutadiene rubber during the 1940s, including synthesis of styrene monomer from coke oven byproducts. Af.er 1951 production of this plant was exclusively directed to the manufacture and polymerisation of styrene. Since 1969 styrene has been produced by catalytic dehydrogenation of ethyl benzene obtained elsewhere. The subjects were volunteers from the local union, with job categories as indicated in Fig. 3; of 668 union members enrolled,
51 were listed as retired.

A detailed occupational and exposure history was taken, and the facts pertinent to this study included present job category and most recent exposure. The job categories were separately classified according to intensity of styrene exposure, with heaviest exposures among styrene polymerisation operators and production workers. Other job categories were ranked according to assessed work histories as having had continuous, intermittent or practically no exposure (Table 1). General exposures were also related to measurements made during a National Institute for Occupational Safety and Health industrial hygiene field survey (Maier and Ruba, 1974). The most recent exposures (date and hour) were recorded.

Blood samples $(10 \mathrm{ml})$ were taken in preheparinised glass vacutainer tubes and frozen until analysed. Urine samples were collected in four-ounce polyethylene jars and frozen until analysed.

\section{STYRENE PRODUCTION AND POLYMERISATION}

ETHYL BENZENE (from vendor)

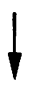

ETHYL BENZENE

CATALYTIC DEHYDROGENATION

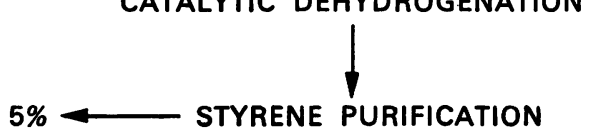

Sold

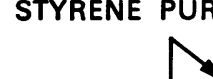

7-10\% used to make copolymer (maleic anhydride) or specialty products

90\% TO POLYSTYRENE

(36 $000000 \mathrm{lb}$ per month)

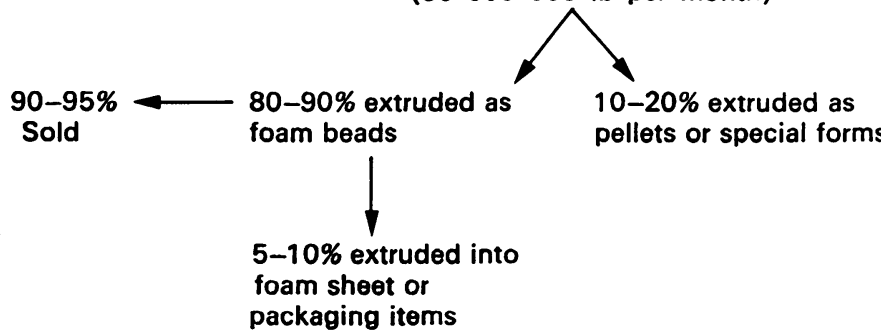

NUMBER OF WORKERS

10

40

40

65

116

77

Fig. 3 Job classifications of styrene production and polymerisation workers according to union seniority list (July, 1975). Other production workers are classified as transportation and storage (59), utility (49) and maintenance (134). 
Table 1 Job classification of styrene polymerisation workers

\begin{tabular}{|c|c|c|c|}
\hline Group & Job description & $\begin{array}{l}\text { Number of } \\
\text { workers }\end{array}$ & $\begin{array}{l}\text { Total in } \\
\text { subdivision }\end{array}$ \\
\hline I & Retired: no current exposure & 47 & 47 \\
\hline II & $\begin{array}{l}\text { Low or no exposure } \\
\text { Unclassified, machinists (1), } \\
\text { garage mechanic (2) } \\
\text { Coal handler and boiler house } \\
\text { workers }\end{array}$ & 21 & \\
\hline & Janitor & 8 & 44 \\
\hline III & $\begin{array}{l}\text { Maintenance: no direct exposure } \\
\text { Craneman, storeroom, insulator, } \\
\text { painter, boilermaker } \\
\text { Electrician } \\
\text { Utility, effluent and coal }\end{array}$ & $\begin{array}{l}18 \\
15\end{array}$ & \\
\hline IV & $\begin{array}{l}\text { handler } \\
\text { Products handlers }\end{array}$ & 14 & 47 \\
\hline & Polystyrene handler & 16 & \\
\hline & Transportation & 15 & \\
\hline & Packaging operator & 25 & \\
\hline & Warehouse materials & 7 & \\
\hline & Polystyrene sheet extrusion & 41 & \\
\hline & Polystyrene extrusion (beads) & 14 & \\
\hline & Latex-specialty & 29 & 146 \\
\hline $\mathbf{V}$ & Maintenance: direct exposure & & \\
\hline & Carpenter & 6 & \\
\hline & Instrument maintenance & 9 & \\
\hline & Labourer & 13 & \\
\hline & Liquid handler & 10 & \\
\hline & Millwright & 19 & \\
\hline & Pipefitter & 29 & \\
\hline & Rigger & 3 & \\
\hline & Welder & 11 & 100 \\
\hline VI & $\begin{array}{l}\text { Styrene manufacture and } \\
\text { purification }\end{array}$ & 29 & 29 \\
\hline $\begin{array}{l}\text { VII } \\
\text { Total }\end{array}$ & Polymerisation workers & 78 & $\begin{array}{r}78 \\
491\end{array}$ \\
\hline
\end{tabular}

ANALYTICAL METHODS

Urinary metabolites of styrene

Urinary mandelic (MA) and phenylglyoxylic (PGA) acids were measured as their methyl esters by gas chromatography using the method of Buchet et al. (1974). This method recently has been shown to yield secondary methylation products, probably involving the alpha-keto moiety, from phenylglyoxylic acid (Schaller et al., 1976) and therefore the values for PGA may be underestimated by $10-20 \%$, as judged by the occasional occurrence of other peaks in standard runs. However, in this investigation freshly prepared standards in the range of $15-150 \mathrm{mg} / \mathrm{l}$ were run daily, and both mandelic and phenylglyoxylic acid produced linear calibration curves by peak height or by electronically integrated area. All samples showing the presence of $15 \mathrm{mg} / \mathrm{l}$ or more were analysed in duplicate and the values averaged. The average standard deviation from the mean of these measurements was $24 \%$, with the absolute deviation generally less than 10 $\mathrm{mg} / \mathrm{l}$ for values below $50 \mathrm{mg} / \mathrm{l}$.

Urinary concentrations were expressed as $\mathrm{mg} / \mathrm{g}$ creatinine, in an effort to normalise values for the dilution of urine. The mean of 153 creatinine measurements was $1.56 \pm 0.8 \mathrm{~g} / 1$ creatinine. Gas chromatographic analyses were performed using a Perkin-Elmer 3920 gas chromatograph with dual flame ionisation detectors and Columbia Scientific electronic integrator, using a $10 \mathrm{ft} \times 1 / 8$ in DEGS on chromosorb column at $120^{\circ} \mathrm{C}, \mathrm{N}_{2}$ flow rate 30 $\mathrm{cc} / \mathrm{min}$.

\section{Styrene in whole blood}

The styrene concentration in blood was determined by spectrofluorometric assay following cyclohexane extraction. Blood $(0.5 \mathrm{ml})$ was combined with an equal volume of freshly distilled cyclohexane in a $16 \times 150 \mathrm{~mm}$ test tube, and after brief centrifugation $(1800 \mathrm{~g})$ the cyclohexane layer was transferred by means of a Pasteur pipette into a quartz cuvette $(0.3 \times 0.3 \mathrm{~cm})$, which was measured at 250 $\mathrm{nm}$ in a MPF4 Hitachi spectrofluorometer. With sufficiently pure cyclohexane, the fluorescence spectrum of the extracted sample was virtually identical to that of styrene dissolved in cyclohexane. The extraction efficiency of styrene in cyclohexane added to blood was $95 \pm 10 \%$, and the fluorescence intensity was proportional to the styrene concentration range of interest here. The sensitivity limit was 1-3 parts per billion, at which level the fluorescence spectrum was still recognisably that of styrene, with a prominent sharp line at $293 \mathrm{~nm}$ and moderately resolved peaks at 303, 307 and $317 \mathrm{~nm}$. A more complete description of this assay will be given elsewhere.

Results

STYRENE POLYMERISATION PLANT

At the time of the examinations polystyrene accounted for over $90 \%$ of the production in this plant, with the remainder of the styrene being used in specialty products including butadiene-styrene copolymer and maleic anhydride-styrene copolymer. Most of the polystyrene was made into expandable polystyrene beads by means of pentane impregnation, and then shipped elsewhere for extrusion into polystyrene foam. Some extrusion of polystyrene was done at the plant (Fig. 3), and less than $10 \%$ of the polystyrene was sold in pellet (non-foam) form.

The major production processes in this plant were semi-automated, so that styrene and ethyl benzene were usually maintained within a closed system. However, workers experienced direct exposure to these chemicals when obtaining quality control samples or when, in the case of polymerisation operators, chemicals had to be added through ports in the reactor vessel.

Maintenance procedures which require repair of leaks in styrene or ethyl benzene pipelines also 
involved intermittent high exposure for maintenance workers.

\section{EXPOSURE INFORMATION OBTAINED FROM JOB HISTORY}

The exposure categories summarised in Table 1 were derived by ranking the subject's present job according to estimated exposure intensity, with those jobs having average styrene exposure of more than $5 \mathrm{ppm}$ in air being ranked as high (groups V, VI, VII), and those jobs in areas with finished polystyrene products, as medium or low (group IV). Those jobs having potential styrene contact on an infrequent or intermittent basis were placed in category V. These exposure estimates were consistent with data available from a NIOSH air sampling study performed in 1974 (Maier and Ruba) and, further, with air sampling data obtained in early 1976 by the company (Table 2). During the period of the examinations reported here the plant was operating below capacity, which could have resulted in lower styrene exposure than usual.

The workers had ceased to be exposed to styrene for varying intervals before examination. According to previously reported metabolic elimination rates, the urinary and blood exposure levels were expected to be time-dependent, and therefore a time factor of 'most recent exposure' was used to aid interpretation of urinary and blood measurements. An uneven distribution within 'most recent exposure' intervals sometimes occurred. Pipefitters, a subgroup of $\mathrm{V}$, had only 2 of 25 in the $0-16 \mathrm{~h}$ group, which is pertinent in evaluating their exposure data, especially as this job category was judged to have significant styrene exposure.

\section{URINARY METABOLITE AND BLOOD STYRENE} DETERMINATIONS

The majority of 477 completed urinary and 364 blood analytical measurements were undetectable or below significantly elevated levels (Table 3 ). In the entire group 31 urinary mandelic acid determinations were higher than $20 \mathrm{mg} / \mathrm{g}$ creatinine (average $53 \pm 33 \mathrm{SD}$ ), and 42 were above $15 \mathrm{mg} / \mathrm{g}(43 \pm 33$ SD), suggesting an average exposure level of about $5 \mathrm{ppm}$ by analogy with Figure 1. There were 28

Table 2 Concentration of styrene in air of a polymerisation plant

\begin{tabular}{|c|c|c|c|c|}
\hline \multirow[t]{3}{*}{ Manufacturing area } & \multicolumn{4}{|c|}{ Mean* concentrations, ppm reported by } \\
\hline & \multicolumn{2}{|l|}{$\mathrm{NIOSH} \dagger$} & \multicolumn{2}{|c|}{ Company $y_{+}^{+}$} \\
\hline & Styrene & Ethyl benzene & Styrene & Ethyl benzene \\
\hline Styrene polymerisation & $\begin{array}{c}17 \quad(15) \\
2 \cdot 5 \S(6)\end{array}$ & $<1$ & $\begin{array}{l}19(22) \\
17(13)\end{array}$ & $3(8)$ \\
\hline Styrene purification & $4 \quad(9)$ & $<1$ & $22(13)$ & $19(13)$ \\
\hline Ethyl benzene cracking & (8) & 3 & 3 & 6 \\
\hline Latex-specialty area & $<5$ & $<1$ & & \\
\hline
\end{tabular}

* Mean of several measurements, $n$, in parentheses.

Range and standard deviation were large, $100-200 \%$ of the mean.

$+1-2$ hour samples.

$\ddagger 8$-hour time-weighted averages.

$\S$ Maleic anhydride-styrene copolymerisation area.

Table 3 Relationship of urinary metabolites and blood styrene in various concentration ranges

\begin{tabular}{|c|c|c|c|c|}
\hline \multicolumn{3}{|l|}{ Urinary metabolites } & \multicolumn{2}{|l|}{ Blood styrene } \\
\hline $\begin{array}{l}\text { Concentration range ( } \mathrm{mg} / \mathrm{g} \\
\text { creatinine) }\end{array}$ & $\begin{array}{l}\text { MA } \\
\text { (no. of determinations in each }\end{array}$ & $\begin{array}{l}P G A \\
\text { h range) }\end{array}$ & Concentration range ( $p p b$ ) & Number of determinations \\
\hline 0 (ND) & 341 & 344 & $0-1$ & 114 \\
\hline 2 (trace) & 77 & 77 & $>1-2$ & 130 \\
\hline $4-8$ & 2 & 3 & $>2-3$ & 48 \\
\hline$>\quad 8-12$ & 11 & 9 & $>3-4$ & 29 \\
\hline$>12-16$ & 10 & 14 & $>4-6$ & 26 \\
\hline$>16-20$ & 5 & 3 & $>6-10$ & 4 \\
\hline $21-28$ & 8 & 10 & $>10-14$ & 3 \\
\hline $29-36$ & 5 & 3 & $>14-20$ & 6 \\
\hline $37-52$ & 9 & 8 & $>20-30$ & 1 \\
\hline $60-8 \mathrm{C}$ & 3 & 3 & $40-50$ & 1 \\
\hline$>80-100$ & 3 & 2 & $70-80$ & 1 \\
\hline$>100-120$ & 2 & - & $>80-90$ & 1 \\
\hline $140-160$ & 1 & - & & \\
\hline Total & 477 & 476 & & 364 \\
\hline
\end{tabular}

MA = mandelic acid $\mathbf{P G A}=$ phenylglyoxylic acid $;$ ND $=$ not detected. 
blood styrene determinations above $5 \mathrm{ppb}$, and 13 above $10 \mathrm{ppb}$ (average $28 \pm 24 \mathrm{SD}$ ). The lower limit of detection for MA and PGA was about $10 \mathrm{mg} / \mathrm{l}$, and the values of urinary creatinine ranged from 0.2 to $3.8 \mathrm{~g} / 1$ (average 1.56 ), which accordingly raised or lowered the concentration of urinary metabolites. Blood styrene levels exceeding $5 \mathrm{ppb}$ were considered to be significantly raised, because this value was consistently higher than background contamination or control sera determinations. Recently exposed subjects in high exposure categories (groups VI, VII, Tables 4 and 5) had the highest prevalence of increased urinary metabolites ( $>5 \mathrm{mg} / \mathrm{g}$ creatinine), blood styrene $(>5 \mathrm{ppb}$ ), and instances in which both values were simultaneously raised.

The preponderant number of cases with detectable urinary metabolites and blood styrene was observed among polymerisation workers (group VII) and styrene production workers (group VI) who had been exposed within $4 \mathrm{~h}$ of examination.
Maintenance workers (group V) also had a higher prevalence of increased urinary metabolites and blood styrene, especially those with very recent exposure, such as millwrights (2/6), labourers $(3 / 5)$, and liquid handlers (1/4); however, pipefitters removed for more than $16 \mathrm{~h}$ from exposure $(5 / 26)$ also had increased metabolite levels, reflecting their previous relatively higher (peak) exposures (Table 6).

In several other subgroups the frequency of detectable urinary metabolites or blood styrene was low. Thus, among 47 retired workers no instance of raised blood styrene was observed and in two cases urinary metabolites were observed at $10 \mathrm{mg} / \mathrm{l}$, the limit of detection. Similarly, in the miscellaneous category of low or non-exposed subjects (group II, Table 4) a low prevalence of raised blood styrene and no detectable urinary metabolites were observed. No history of administration of medication was recorded that could explain the occurrence of MA and PGA in urine of retired persons.

Table 4 Urinary metabolites, blood styrene and styrene in body fat among styrene polymerisation workers

\begin{tabular}{|c|c|c|c|c|c|c|c|}
\hline Group & Job classification & $\begin{array}{l}\text { Time since last } \\
\text { exposure }\end{array}$ & $M A^{*}$ & $P G A^{*}$ & $\begin{array}{l}\text { Blood styrene } \\
>5 \mathrm{ppb}\end{array}$ & $\begin{array}{l}\text { Both } \\
\text { increased } \dagger\end{array}$ & $\begin{array}{l}\text { Styrene in } \\
\text { subcutaneous } \\
\text { fat (ppm) }\end{array}$ \\
\hline I & Retired & $\begin{array}{l}>36 \mathrm{~h} \\
\mathrm{n}=47\end{array}$ & $2 / 47$ & $2 / 47$ & $0 / 37$ & $0 / 37$ & $0 / 1$ \\
\hline II & Low or no exposure & $\begin{aligned} & 0-4 \mathrm{~h} \\
>\quad & 4-16 \\
> & 16-36 \\
> & 36 \mathrm{~h} \\
& n=44\end{aligned}$ & $\begin{array}{l}0 / 11 \\
0 / 11 \\
0 / 2 \\
0 / 18 \\
0 / 42\end{array}$ & $\begin{array}{l}0 / 11 \\
0 / 11 \\
0 / 2 \\
0 / 18 \\
0 / 42\end{array}$ & $\begin{array}{l}1 / 9 \\
0 / 11 \\
1 / 2 \\
1 / 16 \\
3 / 38\end{array}$ & $\begin{array}{l}0 / 1 \\
0 / 11 \\
0 / 2 \\
0 / 16 \\
0 / 38\end{array}$ & \\
\hline III & $\begin{array}{l}\text { Maintenance with no } \\
\text { direct exposure }\end{array}$ & $\begin{aligned} & 0-4 h \\
>\quad & 4-16 \\
> & 16-36 \\
> & 36 h \\
& n=47\end{aligned}$ & $\begin{array}{l}1 / 13 \\
1 / 6 \\
1 / 7 \\
1 / 15 \\
4 / 41\end{array}$ & $\begin{array}{l}1 / 13 \\
1 / 6 \\
1 / 7 \\
1 / 15 \\
4 / 41\end{array}$ & $\begin{array}{l}1 / 8 \\
0 / 4 \\
0 / 7 \\
1 / 14 \\
2 / 33\end{array}$ & $\begin{array}{l}0 / 7 \\
0 / 4 \\
0 / 6 \\
1 / 13 \\
1 / 30\end{array}$ & $\begin{array}{l}1 / 1 \\
0 / 1 \\
0 / 1 \\
0 / 3\end{array}$ \\
\hline IV & Products handlers & $\begin{aligned} & 0-4 \mathrm{~h} \\
> & 4-16 \\
> & 16-36 \\
> & 36 \mathrm{~h} \\
& n=146\end{aligned}$ & $\begin{array}{l}3 / 55 \\
1 / 37 \\
0 / 15 \\
0 / 37 \\
4 / 144\end{array}$ & $\begin{array}{l}3 / 55 \\
1 / 37 \\
0 / 15 \\
0 / 37 \\
4 / 144\end{array}$ & $\begin{array}{l}0 / 39 \\
2 / 29 \\
0 / 10 \\
0 / 33 \\
2 / 111\end{array}$ & $\begin{array}{l}0 / 39 \\
0 / 28 \\
0 / 10 \\
0 / 28 \\
0 / 105\end{array}$ & $\begin{array}{l}0 / 1 \\
0 / 1 \\
0 / 2\end{array}$ \\
\hline V & $\begin{array}{l}\text { Maintenance, with } \\
\text { direct exposure }\end{array}$ & $\begin{aligned} & 0-4 h \\
> & 4-16 \\
> & 16-36 \\
> & 36 h \\
& n=100\end{aligned}$ & $\begin{array}{c}6 / 25 \\
0 / 4 \\
2 / 24 \\
4 / 47 \\
12 / 100\end{array}$ & $\begin{array}{l}4 / 25 \\
0 / 4 \\
1 / 24 \\
4 / 47 \\
9 / 100\end{array}$ & $\begin{array}{l}1 / 21 \\
0 / 3 \\
0 / 20 \\
0 / 38 \\
1 / 82\end{array}$ & $\begin{array}{l}0 / 18 \\
0 / 3 \\
0 / 17 \\
0 / 38 \\
0 / 78\end{array}$ & $\begin{array}{l}1 / 1 \\
\\
2 / 7 \\
3 / 8\end{array}$ \\
\hline VI & $\begin{array}{l}\text { Styrene manufacture } \\
\text { and purification }\end{array}$ & $\begin{aligned} & 0-4 h \\
>\quad & 4-16 \\
> & 16-36 \\
> & 36 h \\
& n=29\end{aligned}$ & $\begin{array}{c}10 / 12 \\
3 / 6 \\
1 / 4 \\
1 / 6 \\
15 / 28\end{array}$ & $\begin{array}{c}10 / 12 \\
3 / 6 \\
1 / 4 \\
1 / 6 \\
15 / 28\end{array}$ & $\begin{array}{l}3 / 11 \\
2 / 6 \\
1 / 3 \\
0 / 5 \\
6 / 25\end{array}$ & $\begin{array}{l}2 / 9 \\
2 / 6 \\
1 / 3 \\
0 / 5 \\
5 / 23\end{array}$ & $\begin{array}{l}2 / 2 \\
\\
0 / 1 \\
2 / 3\end{array}$ \\
\hline VII & $\begin{array}{l}\text { Polystyrene polymerisation } \\
\text { workers }\end{array}$ & 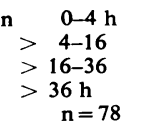 & $\begin{array}{c}18 / 35 \\
3 / 12 \\
0 / 8 \\
0 / 22 \\
22 / 77\end{array}$ & $\begin{array}{c}19 / 35 \\
3 / 12 \\
0 / 8 \\
0 / 22 \\
22 / 77\end{array}$ & $\begin{array}{c}12 / 23 \\
0 / 10 \\
1 / 6 \\
1 / 17 \\
14 / 56\end{array}$ & $\begin{array}{l}7 / 22 \\
0 / 6 \\
0 / 16 \\
7 / 54\end{array}$ & $4 / 4$ \\
\hline
\end{tabular}

* MA and PGA > $5 \mathrm{mg} / \mathrm{g}$ creatinine.

†Simultaneously increased urinary metabolites and blood styrene. 
Table 5 Urinary metabolite and blood styrene concentration among styrene polymerisation workers recently exposed (4h)

\begin{tabular}{|c|c|c|c|c|}
\hline \multirow[t]{2}{*}{ Groups } & \multicolumn{2}{|c|}{ Urinary metabolites raised } & \multirow{2}{*}{$\begin{array}{l}\text { Blood styrene } \\
>5 \mathrm{ppb}\end{array}$} & \multirow[t]{2}{*}{ Both raised } \\
\hline & $\begin{array}{l}M A \\
(>5 m g / g C \dagger)\end{array}$ & $P G A$ & & \\
\hline $\begin{array}{l}\text { Low or unexposed }(\mathrm{II}, \mathrm{III}) \\
\text { Estimated } 1-5 \mathrm{ppm} \text { average exposure* }(\mathrm{IV}, \mathrm{V}) \\
\text { Estimated }>5 \mathrm{ppm} \text { average exposure* (VI, VII) }\end{array}$ & $\begin{array}{r}1 / 23 \\
9 / 80 \\
28 / 47\end{array}$ & $\begin{array}{r}1 / 23 \\
7 / 80 \\
29 / 47\end{array}$ & $\begin{array}{r}2 / 17 \\
1 / 60 \\
15 / 35\end{array}$ & $\begin{array}{l}0 / 16 \\
0 / 57 \\
9 / 31\end{array}$ \\
\hline Total & $38 / 150$ & $37 / 150$ & $18 / 112$ & $9 / 104$ \\
\hline
\end{tabular}

* Based on data of Maier and Ruba, 1974.

$\operatorname{tgC}=\mathbf{g}$ creatinine.

Table 6 Subgroups with significant exposure indicated by urinary metabolites and/or blood styrene concentration*

\begin{tabular}{|c|c|c|c|c|c|}
\hline Workers & Group & Total in group & $\begin{array}{l}\text { Urinary } \\
\text { metabolites } \\
>5 \mathrm{mg} / \mathrm{gC} \dagger\end{array}$ & $\begin{array}{l}\text { Blood styrene } \\
>5 \mathrm{ppb}\end{array}$ & Both raised \\
\hline $\begin{array}{l}\text { Labourer, millwright, instrument maintenance } \\
\text { Latex-specialty and extrusion } \\
\text { Packaging operator } \\
\text { Electrician } \\
\text { Liquid handler } \\
\text { Pipefitter ( }>16 \text { hours only) }\end{array}$ & $\begin{array}{l}\text { V } \\
\text { IV } \\
\text { IV } \\
\text { III } \\
\text { V } \\
\text { V }\end{array}$ & $\begin{array}{r}41 \\
41 \\
26 \\
16 \\
9 \\
28\end{array}$ & $\begin{array}{l}5 / 11 \\
2 / 18 \\
1 / 11 \\
1 / 2 \\
1 / 4 \\
5 / 16\end{array}$ & $\begin{array}{l}1 / 11 \\
0 / 12 \\
1 / 11 \\
0 / 2 \\
0 / 3 \\
1 / 20\end{array}$ & $\begin{array}{l}0 / 11 \\
0 / 12 \\
1 / 11 \\
0 / 1 \\
0 / 2 \\
1 / 19\end{array}$ \\
\hline
\end{tabular}

*Subjects having worked within the past four hours, except for pipefitters.

$+\mathrm{gC}=\mathrm{g}$ creatinine.

CORRELATION OF STYRENE EXPOSURE WITH URINARY METABOLITES AND BLOOD STYRENE

\section{Relative exposure by job category}

The occurrence of increased urinary metabolites and blood styrene paralleled the estimated exposure intensities of job categories (Table 5), with the highest incidence among styrene production and polymerisation workers. The findings for group $\mathrm{V}$ are consistent with significant but intermittent exposure, because of the nature of maintenance work which calls for frequent but not continuous repairs in high styrene exposure areas. The absolute values of the urinary metabolites are consistent with this concept (Tables 3, 9, 10).

Within exposure groups III, IV and V (Table 6), certain job categories were found to account for all but one case of raised urinary or blood metabolites in the larger groups. These included specific maintenance workers and those handling finished polystyrene.

The polymerisation process could be subdivided into four separate areas (Tables 7 and 9), and no significant differences among these subgroups are evident, possibly because of the small number of workers studied.

There were a number of cases with trace urinary metabolites, those near the limit of detection (approx. $7-15 \mathrm{mg} / \mathrm{l}$ ) or values which were reduced to below $10 \mathrm{mg} / \mathrm{g}$ when corrected for creatinine concentration (Table 8). For example, $20 \%$ of 92 products handlers (group IV) showed only traces of urinary metabolites for those exposed within $16 \mathrm{~h}$. In the same group, $6 \%$ had raised urinary metabolites (Table 4). In 11 cases, blood styrene levels were found at trace concentrations (3-4.9 ppb), including nine with raised urinary metabolites.

Subgroups of IV, latex-specialty, with a $40 \%$ incidence of trace urinary metabolites, and extrusion workers with $25 \%$, showed traces of urinary metabolites without concomitant detectable blood styrene concentrations. However, in these groups there were also instances of blood styrene concentrations between 3-4.9 ppb. With the data of Table 6 , these findings suggest low-level exposure for those subgroups.

Trace level metabolites were also observed in 15 of 91 maintenance workers (Table 8, group V) examined more than $16 \mathrm{~h}$ after last exposure. Among 47 recently exposed polymerisation workers, there were 10 cases of trace urinary metabolites and six cases of trace blood styrene, the latter with five coincidentally raised urinary metabolites. The combined number of trace and elevated urinary metabolites for polymerisation workers exposed within $16 \mathrm{~h}$ was $13 / 47$; the comparable number for blood styrene was $18 / 33$. For maintenance workers (group V) more than $16 \mathrm{~h}$ after exposure, 21/71 urinary metabolites and 5/58 blood styrenes were either trace or elevated. 
Table 7 Urinary metabolites, blood styrene and styrene in body fat among styrene workers recently exposed $(\leqslant 4 h)$

\begin{tabular}{|c|c|c|c|c|c|}
\hline \multirow[t]{2}{*}{ Compound } & \multicolumn{2}{|c|}{ Urinary metabolites $>5 \mathrm{mg} / \mathrm{gCC}$} & \multirow[t]{2}{*}{ Blood $>5 p p b$} & \multirow[t]{2}{*}{ Both raised } & \multirow[t]{2}{*}{ Fat styrene } \\
\hline & $M A$ & $P G A$ & & & \\
\hline $\begin{array}{l}\text { Maleic anhydride-styrene copolymer } \\
\text { 'Expandable' polystyrene } \\
\text { Polystyrene area I } \\
\text { Polystyrene II }\end{array}$ & $\begin{array}{l}3 / 4 \\
0 / 2 \\
8 / 19 \\
5 / 7\end{array}$ & $\begin{array}{l}3 / 4 \\
0 / 2 \\
8 / 19 \\
6 / 7\end{array}$ & $\begin{array}{l}2 / 4 \\
1 / 2^{*} \\
8 / 12^{* *} \\
1 / 4\end{array}$ & $\begin{array}{l}2 / 4 \\
0 / 2 \\
4 / 12 \\
1 / 4\end{array}$ & $2 / 2$ \\
\hline Total & $16 / 32$ & $17 / 32$ & $12 / 22$ & $7 / 22$ & $3 / 3$ \\
\hline
\end{tabular}

*'Expandable' polystyrene: one had raised blood styrene without raised urinary MA or PGA. 'Expandable' polystyrene is polymer beads made by using pentane as a blowing agent.

${ }^{* *}$ In polystyrene area I there were four individuals with raised blood styrene, without raised urinary MA or PGA.

Table 8 Urinary metabolites or blood styrene detectable as trace amounts (approx. 5-10 mg/l and 3-5 ppb respectively) among workers in a styrene polymerisation plant

\begin{tabular}{|c|c|c|c|c|c|c|}
\hline \multirow[t]{2}{*}{ Group } & \multirow[t]{2}{*}{ Job classification } & \multirow[t]{2}{*}{ Time since last exposure (h) } & \multicolumn{2}{|c|}{ Number with trace of } & \multirow{2}{*}{$\begin{array}{l}\text { Blood styrene } \\
3-4 \cdot 9 \mathrm{ppb}\end{array}$} & \multirow{2}{*}{$\begin{array}{l}\text { Total in } \\
\text { subgroup }\end{array}$} \\
\hline & & & $M A$ & $P G A$ & & \\
\hline I & Retired & $>36$ & 3 & 4 & $3 \dagger$ & 47 \\
\hline II & Miscellaneous, unexposed & $<16$ & 2 & 2 & $1^{*}$ & 22 \\
\hline \multirow{2}{*}{ III } & Maintenance, incidental or no exposure & $\begin{array}{l}>16 \\
<16\end{array}$ & 2 & $\begin{array}{l}2 \\
3\end{array}$ & $2 *$ & 20 \\
\hline & & $>16$ & 3 & 3 & $5+$ & 22 \\
\hline \multirow[t]{2}{*}{ IV } & Products handling & $<16$ & 19 & 18 & $11 \ddagger$ & 92 \\
\hline & & $>16$ & 4 & 4 & $1^{*}$ & 52 \\
\hline \multirow[t]{2}{*}{ V } & Maintenance with direct exposure & $<16$ & 4 & 4 & $4 \S$ & 29 \\
\hline & & $>16$ & 15 & 15 & 5ा & 91 \\
\hline \multirow[t]{2}{*}{ VI } & Styrene manufacture and purification & $<16$ & - & - & & 18 \\
\hline & & $>16$ & 1 & 1 & & 10 \\
\hline VII & Polystyrene polymerisation workers & $<16$ & 10 & 10 & $6^{* *}$ & 47 \\
\hline \multirow[t]{3}{*}{ Total } & & $\begin{array}{l}>16 \\
<16\end{array}$ & $\begin{array}{r}5 \\
38\end{array}$ & $\begin{array}{r}5 \\
37\end{array}$ & $\begin{array}{l}2^{*} \\
6\end{array}$ & $\begin{array}{r}30 \\
227\end{array}$ \\
\hline & & $>16$ & 33 & 34 & 2 & \\
\hline & & Total & 71 & 71 & 8 & 272 \\
\hline
\end{tabular}

* None of this group had concomitant raised urinary metabolites.

tOne had concomitant raised urinary metabolites.

$\ddagger$ Nine had concomitant raised urinary metabolites.

$\S$ All had concomitant raised urinary metabolites.

TThree of this group had concomitant raised urinary metabolites.

**Five had concomitant raised urinary metabolites.

Table 9 Average concentrations of raised urinary metabolites and blood styrene measurements among styrene polymerisation workers*

\begin{tabular}{|c|c|c|c|c|c|}
\hline \multirow[t]{2}{*}{ Job classification } & \multicolumn{2}{|c|}{$\begin{array}{l}\text { Average urinary metabolite } \\
\text { concentrction }\end{array}$} & \multirow[t]{2}{*}{ Number of subjects } & \multirow[t]{2}{*}{$\begin{array}{l}\text { Average blood styrene } \\
(p p b)\end{array}$} & \multirow[t]{2}{*}{$\begin{array}{l}\text { Number of } \\
\text { subjects }\end{array}$} \\
\hline & $\begin{array}{l}\text { MA } \\
\text { (mg/g creatinine) }\end{array}$ & $P G A$ & & & \\
\hline \multicolumn{6}{|l|}{ Styrene polymerisation } \\
\hline Area I & $35 \pm 28$ & $26 \pm 20$ & (11) & $31 \pm 30$ & (9) \\
\hline Area II & $17 \pm 14$ & $18 \pm 11$ & ( 7 ) & & \\
\hline Styrene manufacture** & $42 \pm 18$ & $20 \pm 10$ & ( 6$)$ & & \\
\hline Styrene purification & $61 \pm 44$ & $51 \pm 32$ & ( 6$)$ & $29 \pm 31$ & (4) \\
\hline Maleic anhydride-styrene copolymerisation & $27 \pm 1$ & $27 \pm 8$ & ( 2) & $7 \pm 2$ & (2) \\
\hline Labourer & $17 \pm 7$ & $13 \pm 13$ & ( 3 ) & & \\
\hline Millwright & $47 \pm 6$ & $16 \pm 19$ & (2) & & \\
\hline Painters & $21 \pm 5$ & $15 \pm 4$ & ( 2) & & \\
\hline
\end{tabular}

* For subgroups with more than one subject having urinary MA or PGA greater than 5 mg/g creatinine and blood styrene greater than 5 ppb.

**For styrene manufacture workers, MA-PGA ratios are different from those of polymerisation workers (P < 0.01). 
Table 10 Mean values of raised urinary metabolites and blood styrene related to time since exposure

\begin{tabular}{lrlll}
\hline $\begin{array}{l}\text { Time since } \\
\text { exposure }(h)\end{array}$ & $N$ & $\begin{array}{l}\text { Urinary } M A, P G A \\
(m g / g C)^{* *}\end{array}$ & $\begin{array}{l}\text { Blood styrene } \\
(p p b)^{* *}\end{array}$ \\
\hline In subjects with urinary metabolic concentration $>5 \mathrm{mg} / \mathrm{gC}^{*}$ \\
$<0 \cdot 7$ & 17 & $41 \pm 32$ & $31 \pm 23$ & $15 \pm 24(\mathrm{n}=11)$ \\
$1-7$ & 14 & $34 \pm 28$ & $23 \pm 22$ & $6 \pm 5 \quad(\mathrm{n}=10)$ \\
$2-4$ & 6 & $20 \pm 15$ & $18 \pm 10$ & $3 \pm 1 \quad(\mathrm{n}=4)$ \\
$7-26$ & 10 & $20 \pm 10$ & $17 \pm 6$ & $4 \pm 2$ \\
$42-48$ & 4 & $12 \pm 4$ & $7 \pm 4$ & $4 \pm 3$
\end{tabular}

In subjects with blood styrene $\geqslant 5 \mathrm{ppb}$

\begin{tabular}{ccccc}
$<0 \cdot 7$ & 7 & $34 \pm 39$ & $32 \pm 32$ & $34 \pm 32$ \\
$1-1 \cdot 7$ & 6 & $35 \pm 41$ & $30 \pm 34$ & $10 \pm 4$ \\
$2-4$ & 4 & $1 \pm 1$ & $1 \pm 1$ & $25 \pm 30$ \\
$7-26$ & 5 & $6 \pm 8$ & $9 \pm 13$ & $6 \pm 1$ \\
$42-48$ & 2 & $6 \pm 6$ & $6 \pm 6$ & $28 \pm 31$ \\
\hline
\end{tabular}

${ }^{*} \mathrm{gC}=\mathrm{g}$ creatinine.

**Mean \pm SD.

\section{Exposure information from concentration of blood} styrene and urinary metabolites

Higher mean concentrations of urinary metabolites were observed among styrene manufacture and purification workers (Table 9). Styrene manufacture workers also had mean mandelic acid concentrations approximately twice that of phenylglyoxylic acid (different from other MA-PGA ratios, $\mathbf{P}<0.01$ ).

An end-of-shift urine could represent a metabolite concentration in the maximum concentration range, only if the subject were exposed within the first few hours of work. The data of Table 10 show a trend toward decreasing concentration of urinary metabolites with increasing time away from the work environment.

Among 42 workers with urinary metabolite values greater than $15 \mathrm{mg} / \mathrm{g}$ creatinine, the mean mandelic acid concentration was $43 \pm 33 \mathrm{mg} / \mathrm{g}$ creatinine, suggesting an average exposure concentration of about $5 \mathrm{ppm}$.

Regression analysis showed no consistent statistically significant relationships between urinary mandelic acid and blood styrene concentrations, a result not unexpected on the basis of the metabolic model (Fig. 4). The correlation between MA and PGA was highly significant (Fig. 5).

For 25 of these workers with subcutaneous fat biopsies (Wolff et al., 1977), styrene in blood and fat and urinary metabolites are now reported in Table 11. Among workers recently exposed (for less than $8 \mathrm{~h}$ ), $8 / 8$ had detectable styrene in fat tissue, $2 / 6$ had blood styrene greater than $5 \mathrm{ppb}$, and $5 / 8$ had increased urinary metabolites. Of the 11 exposed 20-72 h previously, five had detectable styrene in fat, with no instance of raised blood styrene, and two had detectable urinary metabolites.

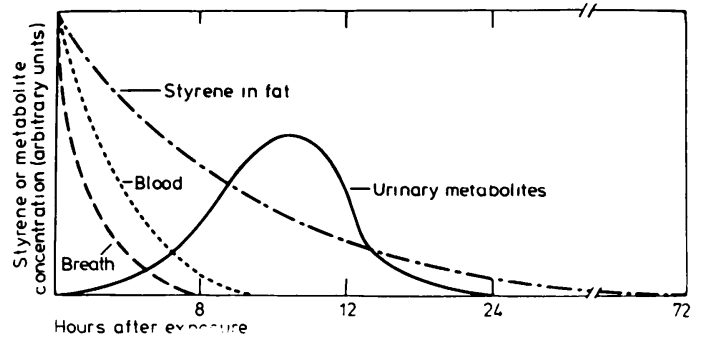

Fig. 4 Metabolic model for styrene elimination.

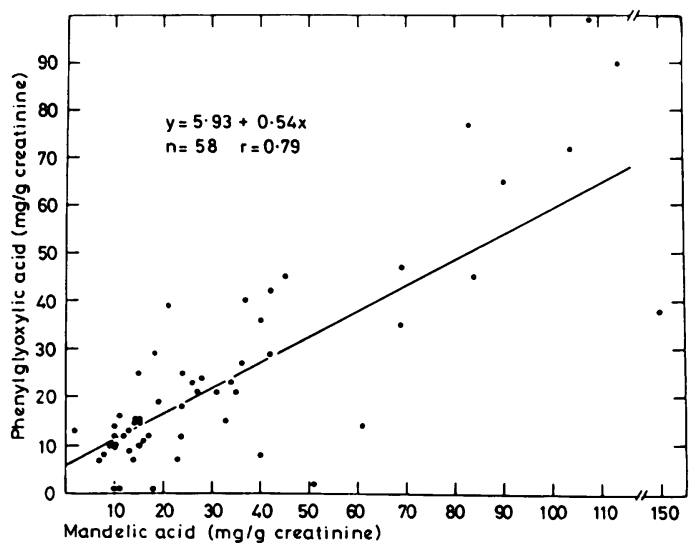

Fig. 5 Correlation of urinary phenylglyoxylic and mandelic acid among 58 styrene polymerisation workers.

\section{Discussion}

Our findings indicate that blood styrene concentrations and urinary metabolite determinations are expedient biological measures of exposure to styrene, even at low concentrations of styrene in air. Blood styrene measurement, using a new analytical method, is useful with very recent exposures, and determination of both factors in cases of high exposure may be used by comparison with the metabolic model (Fig. 4) to estimate previous maximum exposure. Estimation of the fat concentration of organic materials has become possible in selected cases by use of the non-surgical needle biopsy technique to obtain fat for analysis. However, it is not practical for routine daily or weekly screening of working populations.

The present study is unique in its use of biological exposure measurements in such a large working population (491). Blood styrene and urinary metabolite measurements suggested that more than half of the styrene production and polymerisation workers in this plant were exposed to styrene during 
Table 11 Comparison of fat and blood styrene concentration with urinary metabolites

\begin{tabular}{|c|c|c|c|c|}
\hline $\begin{array}{l}\text { Time off } \\
\text { (h) }\end{array}$ & $\begin{array}{l}\text { Estimated* } \\
\text { exposure }\end{array}$ & $\begin{array}{l}\text { Styrene in } \\
\text { fat }(p p m)\end{array}$ & $\begin{array}{l}\text { Styrene in } \\
\text { blood (ppb) }\end{array}$ & $\begin{array}{l}\text { Urinary } \\
M A / P G A \\
(m g / g \\
\text { creatinine })\end{array}$ \\
\hline 0 & - III & $0 \cdot 1$ & NA & 0 \\
\hline 0 & M IV & $0 \cdot 2$ & NA & 0 \\
\hline 3 & M VI & 0.3 & $4 \cdot 2$ & $69 / 35$ \\
\hline 3 & H VII & 0.4 & $8 \cdot 2$ & $26 / 33$ \\
\hline 4 & H VII & 0.8 & $3 \cdot 5$ & $13 / 9$ \\
\hline $4[2]^{*}$ & H VII & $0 \cdot 1$ & 1.6 & $0 / 0$ \\
\hline $4[0.5]$ & H VII & $0 \cdot 3$ & $3 \cdot 5$ & $42 / 29$ \\
\hline $8[1 \cdot 5]$ & M VI & 1.2 & $15 \cdot 4$ & $114 / 90$ \\
\hline 20 & H VII & - ** & 1.4 & 0 \\
\hline 48 & H V & —** & $4 \cdot 7$ & $18 / 0$ \\
\hline $48(96)^{*}$ & H V & -** & $1 \cdot 6$ & $0 / 0$ \\
\hline 48 & M IV & - & 1.9 & 0 \\
\hline 48 & - III & 0.6 & $2 \cdot 8$ & trace \\
\hline 48 & - III & - & $2 \cdot 3$ & 0 \\
\hline 60 & M VII & $0 \cdot 1$ & NA & 0 \\
\hline 60 & M VII & 0.1 & 1.9 & 0 \\
\hline 72 & M VII & 0.3 & $1 \cdot 2$ & 0 \\
\hline 72 & $-\mathbf{V}$ & 0.6 & 1.4 & 0 \\
\hline 72 & L V & - & $2 \cdot 1$ & 0 \\
\hline 96 & M IV & - & 0.7 & 0 \\
\hline 96 & M IV & - & 0.7 & 0 \\
\hline
\end{tabular}

* Time since last exposure in parentheses. Time first examined (urine and blood) in square brackets. Roman numerals correspond to categories in Tables. $\mathbf{H}=$ high; $\mathbf{M}=$ medium; $\mathbf{L}=$ low.

* Small amount of fat reduced sensitivity; therefore unreliable indication of absence of styrene in fat.

$\mathbf{N A}=$ not assessed

the previous eight hours, although even the highest urinary mandelic acid and blood styrene levels $(152 \mathrm{mg} / \mathrm{g}$ creatinine, $85 \mathrm{ppb})$ indicated that the TLV had not been exceeded. Average exposures were estimated to be approximately $5 \mathrm{ppm}$. Thiess et al. (1976) have reported similar urinary metabolite concentrations among a group of 158 workers with styrene exposures below $8 \mathrm{ppm}$ in air. The prevalence of elevated biological exposure indices was well correlated with previously estimated exposure intensities for various subgroups. Thus, more than $50 \%$ of polymerisation and production workers, as groups, had increased urinary metabolites and more than $40 \%$ had raised blood styrene levels. With the number of trace level biological exposure measurements, these frequencies among polymerisation workers became $75.6 \%$ and $54.5 \%$ for urinary metabolites and blood styrene level indices, respectively.

Raised and trace exposure indices at low prevalence in other subgroups appeared to occur within several specific work categories (Tables 6 and 8), although it is not clear that low levels or occasional exposures are confined to these groups. For example, four of 18 packaging operators had detectable or trace urinary metabolites. Although this group was estimated to have low exposure, the presence of styrene monomer in finished polystyrene products is well documented, and more detailed investigation of such workers may be of interest. Maintenance workers involved in repair work in areas of styrene use also appear to have significant though intermittent exposure (Table 4). Among pipefitters especially, relatively high exposure was suggested by the prevalence of $8 / 26$ (five raised and three trace) detectable urinary metabolite levels (average concentration $12 \mathrm{mg} / \mathrm{gc}$ ) for workers removed from exposure for more than $16 \mathrm{~h}$. Production and polymerisation workers with known high exposures had 2/40 such determinations.

The intensity of exposure, suggested by urinary metabolite concentration (Table 9), appears to be greater for styrene manufacture and purification than for polymerisation workers, as in the former groups MA concentration was significantly higher. Furthermore, among styrene manufacture workers, the average concentration of urinary mandelic acid was more than twice that of phenylglyoxylic acid. It may be that workers in this area had a higher exposure to ethyl benzene than in other areas; this may have less efficient metabolic conversion to PGA than to MA. However, the data of Bardodej and Bardodejova (1970), which showed that MA and PGA comprised $64 \%$ and $25 \%$ of ethyl benzene metabolism and $85 \%$ and $10 \%$ of styrene metabolism respectively, do not support this hypothesis. Nevertheless, complex exposures are known to result in metabolic effects different from exposure to either substance alone, at least for toluene-benzene and toluene-styrene exposures (Ikeda et al., 1972), and this may be a factor here as well.

Styrene exposure can be characterised by the interrelation of styrene concentration in breath and blood with urinary metabolite concentration and concentration in fat, as shown in Figure 4.

Several instances of simultaneously raised blood styrene and urinary metabolites were observed among the polymerisation workers, a finding that apparently underlines their higher exposure (see Tables $5,6,7$ and 8). However, several cases were also observed in which blood styrene was raised without a concomitant increase in urinary metabolites (Tables 5 and 8). This may be attributable to very recent exposure, resulting in high blood styrene, before significant excretion of urinary metabolites. Thus, from the metabolic model (Fig. 4), the preferential fat/blood (130) and blood/breath (32) partition (Rees, 1974) causes a rapid decline first in breath, then in blood concentration of styrene. After an initial lag, urinary excretion of mandelic and phenylglyoxylic acids achieves a maximum concentration at 8-16 h after exposure. This metabolite elimination presumably coincides with a substantial depletion of fat-stored styrene, because urinary 
metabolites have been shown to account for $95 \%$ of the styrene absorbed in human subjects (Bardodej and Bardodejova, 1970).

The preferential use of urinary metabolites as a sensitive indicator of styrene exposures is suggested by the more frequent occurrence of raised metabolite levels than of raised blood styrene among this group of workers. Indeed, although the ambient exposures are not available to provide firm evidence for this, the metabolic model (Fig. 4) supports this conclusion. Styrene is extremely fat-soluble, so that the amount absorbed will be preferentially concentrated in the adipose tissue rather than the blood or breath. Thus, blood and breath concentrations are low in comparison. However, metabolism of styrene peaks within 8-12 $\mathrm{h}$ and efficiently eliminates styrene from the fat tissue, as $95 \%$ of that absorbed can be accounted for by urinary metabolites (Bardodej and Bardodejova, 1970). Accordingly, blood concentrations become insignificant (Table 8) within 4-8 $\mathrm{h}$, and in this group of workers were less often detected than were urinary metabolites. Urinary metabolites, however, are excreted over a 8-20 h period with a rather broad maximum (representing a large concentration range) which allows detection in a small urine sample over a fairly long time interval after exposure.

The metabolic model suggests that fat and blood concentrations should be proportional, since an equilibrium exists. In the group examined there were 10 cases with both blood styrene and fat styrene determinations, and here a significant correlation was found ( $\mathrm{r}=0.78$; Fig. 6). However, in contrast to the predictive model (Fig. 4), blood levels are correlated even with urinary mandelic acid in this same small subgroup $(r=0.66)$, suggesting that this correlation is an artefact attributable to the small number of cases involved. As expected, within a larger group with raised urinary MA, the correlation was poor $(r=0 \cdot 12, n=42)$.

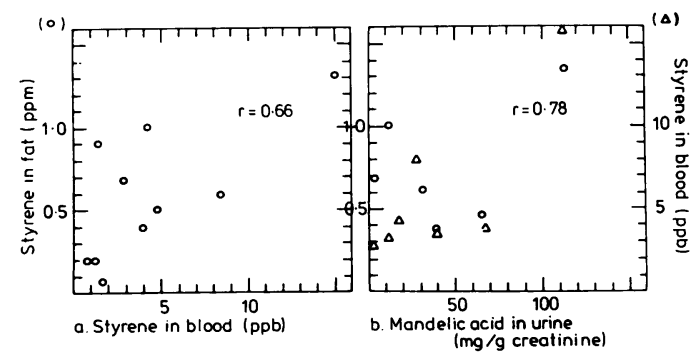

Fig. 6 Relation of styrene in fat to (a) styrene in blood and (b) urinary metabolites. Relation of styrene in blood to urinary metabolites $(\mathrm{b}, \triangle)$.
The partition coefficient of styrene (blood/oil) has been predicted as 130 on the basis of laboratory work (Rees, 1974). Among the subgroup having blood and fat levels, the ratio of fat to blood concentration of styrene ranged from 49-429 with a mean of 150 . While many volume and blood flow factors are neglected, this approximation agrees well with the predicted value.

We thank Drs Josef Eisinger and William Blumberg, Bell Laboratories, Murray Hill, NJ for providing the blood styrene measurements, and for assistance with data analysis. The capable assistance of Lauren Marmor and Jan Nicholson is gratefully acknowledged. Dr Laslo Sarkozi kindly provided urinary creatinine measurements. Support for this work was provided by grants from the National Institute of Environmental Health Sciences ES 00928 and ES 02565.

\section{References}

Astrand, I., Kilbom, A., Ovrum, P., Wahlberg, I., and Vesterberg, O. (1974). Exposure to styrene concentration in alveolar air and blood at rest and during exercise and metabolism. Work-Environment-Health, 11, 69-85.

Astrand, I. (1975). Uptake of solvents in the blood and tissues of man. A review. Scandinavian Journal of Work, Environment and Health, 1, 199-218.

Bardodej, Z., and Bardodejova, E. (1970). Biotransformation of ethyl benzene styrene and alpha-methylstyrene in man. American Industrial Hygiene Association Journal, 31, 206-209.

Buchet, J.-P., Lauwerys, R., and Roels, H. (1974). Evaluation de l'exposition des travailleurs au styrene par le dosage de ses metabolites urinaires; les acides mandelique et phenylglyoxylique. Archives des Maladies Professionelles, de Médecine du Travail et de Sécurité Sociale (Paris), 35, 511516.

Chemical and Engineering News, May 18, 1976, p. 41.

Corbett, T. H. (1973). Retention of anesthetic agents following occupational exposure. Anesthesia and Analgesia, 52, 614-618.

Creech, J. L., and Makk, L. (1975). Liver disease among polyvinyl chloride production workers. Annals of the New York Academy of Sciences, 246, 88-94.

Engstrom, K., and Rantanen, J. (1974). A new gas chromatographic method for determination of mandelic acid in urine. Internationales Archiv für Arbeitsmeaizin, 33, 163-167.

Engstrom, K., Harkonen, H., Kalliokoski, P., and Rantanen, J. (1976). Urinary mandelic acid concentration after occupational exposure to styrene and its use as a biological exposure test. Scandinavian Journal of Work, Environment and Health, 2, 21-26.

Gotell, P., Axelson, O., and Lindelhof, B. (1972). Field studies on human styrene exposure. Work-EnvironmentHealth, 9, 76-83.

Harkonen, H., Kalliokoski, P., Hietala, S., and Hernberg, S. (1974). Concentrations of mandelic and phenylglyoxylic acid in urine as indicators of styrene exposure. Work-Environment-Health, 11, 162-169.

Hunter, C. G., and Blair, D. (1972). Benzene: pharmacokinetic studies in man. Annals of Occupational Hygiene, 15, 193-199. 
Ikeda, M., Ohtsuji, H., and Imamura, T. (1972). In vivo suppression of benzene and styrene oxidation by coadministered toluene in rats and effects of phenobarbital. Xenobiotica, 2, 101-106.

Lee, H. C. Presented at Conference on Toxicology of Vinyl Chloride and Related Olefins at Bethesda, Maryland, May 1977. To be published in Environmental Health Perspectives.

Maier, A., and Ruba, R. (1974). US Department of Health, Education and Welfare, National Institute for Occupational Safety and Health, Cincinnati, Ohio. Health Hazard Evaluation Determination, Report No. 872-9C-107, February 1974.

Maltoni, C., and Lefemine, G. (1975). Carcinogenicity bioassays of vinyl chloride; current results. Annals of the New York Academy of Sciences, 246, 195-218.

Maltoni, C. Presented at Conference on Toxicology of Vinyl Chloride and Related Olefins at Bethesda, Maryland, May 1977. To be published in Environmental Health Perspectives.

Milvy, P., and Garro, A. (1976). Mutagenic activity of styrene oxide (1,2-epoxy-ethylbenzens), a presumed styrene metabolite. Mutation Research, 40, 15-18.

Murray, F. J., Nitschke, K. D., John, J. A., Smith, F. A., Quast, J. F., Blogg, C. D., and Schwetz, B. A. (1976). Teratologic Evaluation of Acrylonitrile Monomer Given to Rats by Gavage. Manufacturing Chemists Association, 1825 Connecticut Ave., NW, Washington, DC, USA.

Ohtsuji, H., and Ikeda, M. (1970). A rapid colorimetric method for the determination of phenylglyoxylic and mandelic acids, and its application to the urinalysis of workers exposed to styrene vapour. British Journal of Industrial Medicine, 27, 150-154.

Rees, H. V. (1974). The partition coefficients of styrene between blood and air and between oil and blood. Internationales Archiv für Arbeitsmedizin, 33, 39-47.
Riley, E. C., Fassett, D. W., and Sutton, W. L. (1966). Methylene chloride vapour in expired air of human subjects. American Industrial Hygiene Association Journal, 27, 346-348.

Schaller, K.-H., Gossler, K., Bost, H.-P., and Valentin, H. (1976). Gas chromatographic methods for determination of styrene in blood and mandelic acid and phenylglyoxylic acid in urine. Arbeitsmedizin Socialmedizin Präventivmedizin, 11, 24-26; 63-64.

Sherwood, R. J. (1972). Evaluation of exposure to benzene vapour during the loading of petrol. British Journal of Industrial Medicine, 29, 65-69.

Slob, A. (1973). A new method for determination of mandelic acid excretion at low level styrene exposure. British Journal of Industrial Medicine, 30, 390-393.

Stewart, R. D., Dodd, H. C., Baretta, E. D., and Schaffer, A. W. (1968). Human exposure to styrene vapor. Archives of Environmental Health, 16, 656-662.

Stewart, R. D., Dodd, H. C., Gay, H., and Erley, D. S. (1970). Experimental human exposure to trichloroethylene. Archives of Environmental Health, 20, 64-71.

Szadkowski, D., Pett, R., Angerer, J., Manz, A., and Lehnert, G. (1973). Toluene concentrations in blood and excretion rates of metabolites in urine in the supervision of printing workers. Internationales Archiv für Arbeitsmedizin, 31, 265-276.

Thiess, A. M., Friedheim, M., and Rossman, H. (1976). Occupational medical investigations on workers employed in styrene polymerization. Paper presented at the April, 1976 meeting of the American Chemical Society, New York.

Wolff, M. S., Daum, S. M., Lorimer, W. V., Selikoff, I. J., and Aubrey, B. B. (1977). Styrene and related hydrocarbons in subcutaneous fat from polymerization workers. Journal of Toxicology and Environmental Health, 2, 997-1005. 